\title{
Effects of Adding Eggshell Powder and Olive Seed Powder to Biscuit Formulation on Some Quality Properties
}

\author{
Ertan Ermiş ${ }^{1, a, *}$, Betül Kevser Tuğla ${ }^{1, b}$, Büşra Külsoy ${ }^{1, c}$ \\ ${ }^{1}$ Food Engineering Department, Faculty of Engineering and Natural Sciences, İstanbul Sabahattin Zaim University, 34303 İstanbul, Turkey \\ *Corresponding author

\begin{tabular}{l|l} 
A R T I C L E I N F O & A B S T R A C T \\
\hline Research Article & $\begin{array}{l}\text { In this study, it was aimed to evaluate the effects of adding olive seed powder (OSP) and eggshell } \\
\text { powder (ESP) to whole wheat biscuit formulation on some of the physico-chemical, chemical, } \\
\text { textural and sensory properties. Incorporation of powder materials was done by adding to biscuit } \\
\text { dough at prespecified concentrations of OSP (7.5\% and 15\%) and ESP (2.5\%) based on total wheat } \\
\text { flour. The data obtained from this study revealed that fortification with powder materials affected } \\
\text { protein and moisture content of final product. Additionally, adding powder materials to whole wheat } \\
\text { biscuit formulation increased the total amount of phenolics and antioxidant activity significantly. } \\
\text { Results of instrumental colour analysis indicated that fortification increased darkness and redness } \\
\text { when compared with the control. Sensory analysis data indicated that non-fortified and fortified } \\
\text { Accepted : } 24 / 11 / 2020\end{array}$ \\
samples provided similar sensory attributes.
\end{tabular}

\begin{abstract}
In this study, it was aimed to evaluate the effects of adding olive seed powder (OSP) and eggshel powder (ESP) to whole wheat biscuit formulation on some of the physico-chemical, chemical, dough at prespecified concentrations of OSP $(7.5 \%$ and $15 \%)$ and ESP flour. The data obtained from this study revealed that fortification with powder materials affected protein and moisture content of final product. Additionally, adding powder materials to whole wheat
\end{abstract} \\ when compared with the control. Sensory
samples provided similar sensory attributes.
}

Biscuit

Antioxidants

Minerals

Acceptability
Egg shell powder

Acceptability
Egg shell powder

\section{Introduction}

There has been a rise of demand to healthier and functional foods in the recent decades. By doing so, utilization of food by-products which are rich in minerals and bioactive substances has gained more attention to add value to the product and to lower environmental drawbacks of food processing by-products. Due to market forecasts, there will be a strong biscuit sales growth by 2020, and the producers are expected to introduce healthier and functional products to the market (Cukelj et al., 2016). Since biscuits are popular and consumed regularly by various groups of consumers, adding functional ingredients to develop functional biscuits have been payed attention (Caponio et al., 2015). Biscuits are appropriate products to incorporate different ingredients into the diet due to its convenience of consumption (easy-to-carry) and long shelf-life. Previously, biscuits were fortified with different ingredients such as mango peel powder (Aslam et al., 2015), flaxseed powder (Čukelj et al., 2017), bee pollen
(Krystyjan et al., 2015), fermented soybean meal (Silva et al., 2018), grape marc extract (Pasqualone et al., 2014), grape pomace (Mildner-Szkudlarz et al., 2013), mint (Bajaj et al., 2006), bamboo shoot powder (Choudhury et al., 2015) chickpea flour and broad bean flour (Rababah et al., 2006), defatted groundnut paste (Dauda et al., 2018) and purple wheat (Caponio et al., 2015).

Eggshells as by-product of the food industry, have significant level of calcium (Afzal et al., 2020; Naves et al., 2007) and olive seeds (olive stone, olive pits) have bioactive and valuable compounds (Rodríguez et al., 2008). Innovative food applications of olive by-products (i.e., the improvement of nutritional functionality and sensory quality of enriched food) has been discussed by Nunes et al. (2016). Eggshells were studied as adsorbent (Mittal et al., 2016), added in baked starch foam and used in biodiesel production (Niju et al., 2014). High amount of calcium $(\mathrm{Ca})$ [around $40 \%$, in the form of calcium 
carbonate $(98.43 \%)$ and calcium phosphate $(0.75 \%)]$ as well as magnesium $(\mathrm{Mg})$ (around $0.5 \%$ ) and phosphorus (P) (around $0.1 \%$ ) were found in eggshells. In some previous studies, ESP has been used in muffins (Afzal et al., 2020), butter cake (Salem et al., 2012) and milk (Fina et al., 2016). In addition, eggshells were used for calcium fortification of fermented pork sausage (Daengprok et al., 2002) and it has been reported that, they can be used to fortify some other foods (Brun et al., 2013; Naves et al., 2007). Therefore, fortification of biscuits with ESP and OSP could significantly broaden the supply of pro-health biscuits as well as reduce the environmental drawbacks of by-products.

This work aimed to develop a biscuit product enriched with ESP and OSP which are by-products of food processing. In this study, the combined effect of these powders on total phenolics, total antioxidant activity, mineral content, physical properties and consumers' acceptance of biscuit samples were investigated.

\section{Materials and Methods}

Medium range white eggs, olives (black, fermented, salted, XL size), whole wheat flour, wheat flour, pounded oats, coconut oil, sunflower oil, butter, eggs, iced sugar, invert sugar, vanilla flavor and baking powder were purchased from the local market.

\section{Preparation of ESP and OSP}

Egg shells were sterilised at $121^{\circ} \mathrm{C}$ for $15 \mathrm{~min}$ in an autoclave after washed with tap water. They left 2 days at $60^{\circ} \mathrm{C}$ for drying to get the final moisture content around $12 \%$. Dried eggshells were milled using a centrifuge mill (Retsch-zm 200, Retsch, Germany) at $10000 \mathrm{rpm}$.

Olive seeds were washed prior to drying process in an oven at $100^{\circ} \mathrm{C}$ for 4 hours to get the final moisture content around $12 \%$. Dried seeds were milled using a hammer mill (Polymix, Kinematica, Switzerland) at $6000 \mathrm{rpm}$ prior to size reduction in the centrifuge mill at $10000 \mathrm{rpm}$. Both ESP and OSP samples were sieved by laboratory bench size sieves (Retsch-AS 200) (Restsch, Germany). The powder fractions below $100 \mu \mathrm{m}$ size were used in biscuit production.

\section{Biscuits Preparation}

The method reported by Krystyjan et al. (2015) with some modifications was used to obtain the dough and baked biscuits. Dry ingredients presented in Table 1 were mixed together to obtain dough structure. The biscuits with OSP substitution in amounts of $0,7.5$ and $15 \%$ - in relation to the total amount of wheat flour - were prepared in the same way as the control sample (biscuits without ESP and OSP). ESP was added to biscuit samples at a concentration of $2.5 \%$ (based on total wheat flour). The dough was mixed for $10 \mathrm{~min}$ at around $20^{\circ} \mathrm{C}$ to achieve a homogeneous consistency and then left 30 min for resting and maturation. The dough was then rolled out and $5 \mathrm{~mm}$ thick biscuits with a $60 \mathrm{~mm}$ diameter were formed and baked at $200^{\circ} \mathrm{C}$ for $10 \mathrm{~min}$. These were then stored in glass containers at around $20^{\circ} \mathrm{C}$ until conducting the analyses.

\section{Determination of Proximate Composition of Biscuits}

The chemical compositions of biscuit samples were analysed according to the methods of the American Association of Cereal Chemists (AACC, 2009). Moisture content, ash content, protein content and fat content analyses were conducted according to AACC 44-19.01, AACC 0801.01, AACC 46-12.01 and AACC 30-25.01, respectively.

\section{Preparation of Extracts for Total Phenolic Content (TPC) and Antioxidant Activity (AA) Analyses}

The extract preparation for total phenolic content (TPC) and antioxidant activity (AA) analyses were done according to methods reported previously (Apak et al., 2006; Grasso et al., 2019). For this purpose, $20 \mathrm{~mL}$ of absolute methanol was mixed with $1 \mathrm{~g}$ of sample prior to resting the mixture 1 hour at ambient temperature. Then, the mixture was centrifuged for $10 \mathrm{~min}$ at $1.5 \mathrm{x} \mathrm{g}$. the supernatant was used for TPC and AA analyses.

\section{Determination of TPC and $A A$}

For the determination of TPC, $0.1 \mathrm{~mL}$ of extract was taken and mixed with $1.5 \mathrm{~mL}$ of distilled water and $0.1 \mathrm{~mL}$ of Folin-Ciocalteu phenol reagent (1:1) and homogenized. After resting for $5 \mathrm{~min}, 0.3 \mathrm{~mL}$ of $20 \% \mathrm{Na} 2 \mathrm{CO} 3$ solution was added and vortexed. The mixture was incubated for 60 min at room temperature in dark. The absorbances at 765 $\mathrm{nm}$ were measured in standard cuvettes using a Shimadzu UV-1280 UV-vis spectrophotometer (Kyoto, Japan) against a regent blank. The results were expressed as $\mu \mathrm{mol}$ of gallic acid equivalent (GAE) per $g$ of dry matter.

For the determination of the cupric reducing antioxidant capacity (CUPRAC), $1.1 \mathrm{~mL}$ of extract was added to the mixture containing $1 \mathrm{~mL}$ of $7.5 \mathrm{mM}$ neocuproine solution, $1 \mathrm{~mL}$ of $10 \mathrm{mM}$ copper chloride (II) and $1 \mathrm{~mL}$ of NH4Ac buffer (pH 7.0). The final mixture was incubated for $1.5 \mathrm{~h}$ at room temperature. The absorbances at $450 \mathrm{~nm}$ were measured and the results were given as $\mu \mathrm{mol}$ Trolox equivalents per $\mathrm{g}(\mu \mathrm{mol} \mathrm{TE} / \mathrm{g})$.

\section{Mineral Analysis}

An inductively coupled plasma-mass spectrometer (Agilent 7700 ICP-MS) was employed to determine mineral elements (Fe, $\mathrm{Ca}, \mathrm{Mg}, \mathrm{Na}, \mathrm{P}, \mathrm{Zn}$ and $\mathrm{Se}$ ) in biscuit samples. Sample preparation, analytical procedure and analytical parameters were followed as given by Chudzinska and Baralkiewicz (2010).

\section{Determination of Physical Characteristics}

A TA-XT plus Texture Analyzer (Stable Micro System, Haslemere, UK), equipped with a $5 \mathrm{~kg}$ load cell and heavyduty platform was used to analyse hardness of biscuits $(\mathrm{n}=10)$ at $20 \pm 2{ }^{\circ} \mathrm{C}$. Hardness and brittleness were measured by compressing biscuits with a $75 \mathrm{~mm}$ diameter P/75 aluminium probe (Silva et al., 2018). The test speed was set to $3.0 \mathrm{mms}^{-1}$. Maximum force (the value of force needed to crack the biscuit in Newton) was determined from the force-time curves obtained.

The colour properties of biscuit samples were determined using a colorimeter (Minolta CR 400) (Konica Minolta, Osaka, Japan). The CIELab $L^{*}$ (0 black, 100 white), $a^{*}$ (- green, +0 red), $b^{*}$ (- blue, + yellow) colour components were analysed (Silva et al., 2018). The tests were repeated 3 times. 
Table 1. Ingredients used for the preparation of biscuit dough

\begin{tabular}{l|ccc}
\hline \multicolumn{1}{c}{ Components [\%(wt/wt)] } & CS & B1 & B2 \\
\hline Wheat flour & 20 & 20 & 20 \\
Whole wheat flour & 20 & 18 & 17 \\
Pounded oats & 20 & 18 & 16 \\
Coconut oil & 5.5 & 5.5 & 5.5 \\
Sunflower oil & 4 & 4 & 4 \\
Butter & 2.5 & 2.5 & 2.5 \\
Eggs (whole) & 1.5 & 1.5 & 1.5 \\
Icing sugar & 15 & 15 & 15 \\
Invert sugar & 6 & 6 & 6 \\
Cinnamon powder & 0.35 & 0.35 & 0.35 \\
Vanilla powder & 0.4 & 0.4 & 0.4 \\
Baking powder & 3.5 & 3.5 & 3.5 \\
Salt & 1.25 & 1.25 & 1.25 \\
ESP & 0 & 1 & 1 \\
OSP & 0 & 3 & 6
\end{tabular}

CS: Control Sample, ESP: Egg Shell Powder, OSP: Olive Seed Powder, B1, B2: biscuit samples

\section{Sensory Analysis}

12 trained panellists were recruited to carry out sensory acceptance test. The samples were coded with three random letter and digits numbers and given to panellists in random order. Bottled water was offered to panellists to clean their mouth between evaluating different biscuit samples. A five-point hedonic scale was used to evaluate general appearance, colour, hardness, chew ability, distribution in mouth, taste and overall acceptability of biscuits, ranging from "dislike very much" (point 1) to "like very much" (point 5).

\section{Statistical Analysis}

Analysis of variance was applied to the experimental data at the confidence level of $\mathrm{P}<0.05$, using Minitab 17 software (Minitab Inc., Pennsylvania USA). The test of Tukey's HSD was used to determine statistically significant differences.

\section{Results and Discussion}

\section{Chemical Composition of Biscuits}

Even though all biscuit samples were in edible status, they were noticeably different in terms of appearance (Figure. 1C, 1D and 1E). Table 2 exhibits the chemical composition of biscuit samples. One can notice that the addition of ESP and OSP caused a decrease in moisture content which ranged from 4.85 to $3.86 \%$. It was also found that there was an increase in ash and protein contents in the samples which was fortified with ESP and OSP. The ash content of biscuit sample fortified with ESP and OSP showed a significant increase, high level of ash was noticed in B2 with $1 \mathrm{~g}$ of ESP and $6 \mathrm{~g}$ of OSP $(1.87 \pm 0.04 \%)$ followed by B1 with $1 \mathrm{~g}$ of ESP and $3 \mathrm{~g}$ of OSP $(1.77 \pm 0.03 \%)$ and the lowest in CS $(1.38 \pm 0.13)$ (Table 2$)$. An increase in the ash content and protein content might be attributed to the rich mineral content found in ESP and some amount of protein that may be found in OSP. The results obtained for $\mathrm{CS}$ are in agreement with those reported by Krystyjan et al. (2015) and Silva et al. (2018). However, the addition of ESP and OSP caused slight differences in fat content of the samples. The results fluctuated around $13.4 \%$. Afzal et al. (2020) have reported that the fat content of eggshell fortified muffins decreased as the amount of added eggshell powder increased. However, in this study, slight differences in the fat content of ESP and OSP fortified biscuit samples were observed when compared to control sample. This result might be attributed to the fat fraction present in OSP which contributed to the total fat content of biscuits.

\section{Total Phenolics and Antioxidant Activity}

It was reported that oil seeds and nuts are rich in TPC, flavonoids, flavan-3-ols and condensed tannins (Sarkis et al., 2014). According to a recent study, olive seeds contain phenolic compounds ranging from 3.56 to $11.32 \mathrm{mg} \mathrm{g}^{-1}$ of gallic acid equivalent (GAE) of dry weight depending on the variety and maturity (Elbir et al., 2015). It was reported that baking process reduce the recovery TPC due to some adverse effects of thermal treatment (Rupasinghe et al., 2008). Pasqualone et al. (2014) compared the TPC of flour samples and biscuits and they report a significant decrease in the amount of TPC after baking process. Fortification of biscuits with OSP, which has a certain amount of phenolics, and baking process may affect the phenolic content of final product. Based on the data given in Table 3, it can be seen that the content of total phenolics increased in terms of GAE in parallel with the level of OSP addition. The data shown in Table 3 revealed that the increase in TPC and AA of $1 \mathrm{~g}$ ESP and $6 \mathrm{~g}$ OSP added biscuit samples were statistically significant. The data obtained in this study (ranged from 32.1 to $37.4 \mu \mathrm{mol} \mathrm{g}{ }^{-1} \mathrm{GAE}$ ) showed higher than those reported in literature (Čukelj et al., 2017; Silva et al., 2018). The AA is expected to be at a certain level due to the presence of phenolics and other bioactive compounds. The AA of biscuit samples increased (ranged from 12.0 to $18.3 \mu \mathrm{mol} \mathrm{g}{ }^{-1}$ trolox equivalent (TE) at dry basis with the addition of OSP when compared to the control sample (Table 3). The findings found in literature are lower than the data obtained from this study (Caponio et al., 2015; Čukelj et al., 2017). The reason might be attributed to the difference in the formulations used to prepare biscuit dough.

\section{Minerals Composition}

Since eggshells are good source of calcium (Naves et al., 2007), eggshell fortified foods exhibited a significant increase in calcium concentration (Afzal et al., 2020). As can be observed from Table 3, the control biscuit samples (CS) had significant amount of minerals which were possibly sourced from whole wheat flour and pounded oats. The amount of calcium in control sample (SC) $(2.35 \pm 0.06$ $\mathrm{mg} / 100 \mathrm{~g}$ ) was much lower than others except iron. However, for the biscuit samples B1 and B2, the amount of $\mathrm{Ca}$ increased dramatically $(20.93 \pm 0.54 \mathrm{mg} / 100 \mathrm{~g}$ and $19.19 \pm 0.50 \mathrm{mg} / 100 \mathrm{~g}$, respectively). This might be attributed to the addition of ESP which is rich in Ca mineral. While the changes in the amount of Sodium (Na) and Magnesium $(\mathrm{Mg})$ were not significant $(\mathrm{P}<0.05)$, increases in the level of Iron (Fe), Zinc (Zn) and Phosphorus (P) were significant $(\mathrm{P}<0.05)$. The increases in mineral contents of fortified biscuit samples are considered as a result of addition of the biscuit samples with OSP and ESP. Enrichment of mineral content of biscuits through fortification with food processing by-products can be considered as a viable strategy for counteracting mineral deficiencies in children and adolescents (Adebiyi et al., 2017). 
Table 2. Proximate composition of biscuit samples (g/100 g; mean \pm std.dev., $\mathrm{n}=3$ ).

\begin{tabular}{l|cccc}
\hline \multicolumn{1}{c|}{ Sample } & Moisture & Ash & Protein & Fat \\
\hline CS & $4.85^{\mathrm{a}} \pm 0.06$ & $1.38^{\mathrm{c}} \pm 0.13$ & $9.07^{\mathrm{b}} \pm 0.10$ & $13.61^{\mathrm{a}} \pm 0.11$ \\
B1 & $4.05^{\mathrm{b}} \pm 0.04$ & $1.77^{\mathrm{b}} \pm 0.03$ & $9.19^{\mathrm{a}} \pm 1.29$ & $13.39^{\mathrm{b}} \pm 0.10$ \\
B2 & $3.86^{\mathrm{c}} \pm 0.06$ & $1.87^{\mathrm{a}} \pm 0.04$ & $9.89^{\mathrm{a}} \pm 0.14$ & $13.55^{\mathrm{ab}_{ \pm}} \pm 0.14$ \\
\hline
\end{tabular}

CS: Control Sample, B1:1 g ESP+3 g OSP, B2: 1 g ESP+6 g OSP, ESP: Egg Shell Powder, OSP: Olive Seed Powder, Different letters in the same column indicates significant, differences at level of confidence $\mathrm{P}<0.05$

Table 3. The mineral content ( $\mathrm{mg} / 100 \mathrm{~g})$, antioxidant activity $\left(\mu \mathrm{mol} \mathrm{g} \mathrm{g}^{-1} \mathrm{TE}\right)$ and total phenolic content $\left(\mu \mathrm{mol} \mathrm{g} \mathrm{g}^{-1} \mathrm{GAE}\right)$ of biscuit samples $(n=3)$

\begin{tabular}{l|ccc}
\hline \multicolumn{1}{c|}{ Element } & $\mathrm{CS}$ & $\mathrm{B} 1$ & $\mathrm{~B} 2$ \\
\hline $\mathrm{Na}$ & $1135^{\mathrm{a}} \pm 141$ & $1261^{\mathrm{a}} \pm 156$ & $1361^{\mathrm{a}} \pm 169$ \\
$\mathrm{Mg}$ & $336.6^{\mathrm{a}} \pm 22.8$ & $338.0^{\mathrm{a}} \pm 22.8$ & $343.6^{\mathrm{a}} \pm 23.2$ \\
$\mathrm{Ca}$ & $2.35^{\mathrm{c}} \pm 0.06$ & $20.93^{\mathrm{a}} \pm 0.54$ & $19.19^{\mathrm{b}} \pm 0.50$ \\
$\mathrm{Fe}$ & $602.91^{\mathrm{c}} \pm 6.27$ & $643.40^{\mathrm{b}} \pm 6.69$ & $754.61^{\mathrm{a}} \pm 7.85$ \\
$\mathrm{Zn}$ & $7.20^{\mathrm{b}} \pm 0.27$ & $7.13^{\mathrm{b}} \pm 0.27$ & $8.67^{\mathrm{a}} \pm 0.32$ \\
$\mathrm{P}$ & $865.4^{\mathrm{b}} \pm 34.4$ & $1027^{\mathrm{a}} \pm 41$ & $974.2^{\mathrm{a}} \pm 38.7$ \\
$\mathrm{Se}$ & nd & nd & nd \\
$\mathrm{AA}$ & $12.0^{\mathrm{c}} \pm 0.4$ & $15.2^{\mathrm{b}} \pm 0.7$ & $18.3^{\mathrm{a}} \pm 0.6$ \\
$\mathrm{TPC}$ & $32.1^{\mathrm{b}} \pm 0.8$ & $35.6^{\mathrm{a}} \pm 1.0$ & $37.4^{\mathrm{a}} \pm 1.2$ \\
\hline
\end{tabular}

CS: Control Sample, B1:1 g ESP+3 g OSP, B2: $1 \mathrm{~g}$ ESP+6 g OSP, ESP: Egg Shell Powder, OSP: Olive Seed Powder, AA: Antioxidant Activity, TPC: Total Phenolic Content, TE: Trolox Equivalent, GAE: Gallic Acid Equivalent, Different letters in the same row indicates significant differences at level of confidence $\mathrm{P}<0.05$

Table 4. Physical properties (color attributes and fracture strength) $(n=3)$

\begin{tabular}{l|cccc}
\hline & $L^{*}$ & $a^{*}$ & $b^{*}$ & Hardness [N] \\
\hline CS & $65.25^{\mathrm{a}} \pm 1.68$ & $6.02^{\mathrm{b}} \pm 0.46$ & $23.13^{\mathrm{a}} \pm 1.09$ & $1577^{\mathrm{a}} \pm 177$ \\
B1 & $61.12^{\mathrm{b}} \pm 1.09$ & $8.18^{\mathrm{a}} \pm 0.19$ & $21.62^{\mathrm{a}} \pm 0.90$ & $1330^{\mathrm{a}} \pm 463$ \\
B2 & $59.52^{\mathrm{b}} \pm 1.50$ & $8.49^{\mathrm{a}} \pm 0.69$ & $20.42^{\mathrm{b}} \pm 0.24$ & $1320^{\mathrm{a}} \pm 719$ \\
\hline
\end{tabular}

$L^{*}$ (0 black to 100 white), $a^{*}$ (- green to + red), $b^{*}$ (- blue to + yellow), CS: Control Sample, B1:1 g ESP+3 g OSP, B2: $1 \mathrm{~g}$ ESP+6 g OSP, ESP: Egg Shell Powder, OSP: Olive Seed Powder, N: Newton, Different letters in the same coloumn indicates significant differences, at level of confidence $\mathrm{P}<0.05$

Table 5. Sensory analysis scores $(\mathrm{n}=10)$

\begin{tabular}{c|ccc}
\hline Attributes & CS & B1 & B2 \\
\hline General appearance & $3.83^{\mathrm{a}} \pm 0.83$ & $4.00^{\mathrm{a}} \pm 0.74$ & $3.92^{\mathrm{a}} \pm 0.90$ \\
Colour & $3.92^{\mathrm{a}} \pm 0.51$ & $4.08^{\mathrm{a}} \pm 0.51$ & $4.00^{\mathrm{a}} \pm 0.74$ \\
Hardness & $4.08^{\mathrm{a}} \pm 0.79$ & $3.75^{\mathrm{a}} \pm 1.05$ & $4.08^{\mathrm{a}} \pm 1.24$ \\
Chewability & $4.08^{\mathrm{a}} \pm 0.79$ & $3.75^{\mathrm{a}} \pm 0.96$ & $3.50^{\mathrm{a}} \pm 1.00$ \\
Distribution in mouth & $3.50^{\mathrm{a}} \pm 0.90$ & $3.75^{\mathrm{a}} \pm 0.86$ & $3.83^{\mathrm{a}} \pm 1.11$ \\
Taste & $4.17^{\mathrm{a}} \pm 0.72$ & $3.92^{\mathrm{a}} \pm 0.67$ & $3.83^{\mathrm{a}} \pm 1.03$ \\
Overall acceptability & $3.75^{\mathrm{a}} \pm 0.45$ & $3.75^{\mathrm{a}} \pm 0.75$ & $3.58^{\mathrm{a}} \pm 1.24$ \\
\hline
\end{tabular}

CS: Control Sample, B1:1 g ESP+3 g OSP, B2: $1 \mathrm{~g}$ ESP+6 g OSP, ESP: Egg Shell Powder, OSP: Olive Seed Powder, Different letters in the same row indicates significant differences at level of confidence $\mathrm{P}<0.05$

\section{Physical Characteristics}

Color is one of the important parameters used to evaluate consumer acceptance and used for process control during oven-cooking. According to the data given in Table 4, B2 samples have the darkest $\left(L^{*}\right)(59.52 \pm 1.50)$ and reddest $\left(a^{*}\right)(8.49 \pm 0.69)$ color attributes when compared to B1 and CS while CS was noted as the yellowest $\left(b^{*}\right)$ $(23.13 \pm 1.09)$ and lightest $\left(L^{*}\right)(65.25 \pm 1.68)$. The reason of biscuit color changing might be linked to brown color of OSP and explains why B2 samples have the darkest and reddest color. This is indicative of the existence of a browner colour on the biscuit samples. The changes in color properties could be attributed to the effect of ESP (white) and OSP (brown) (as seen in Figure. 1A and 1B, respectively), which were added to the biscuit samples at different concentrations. Another reason might be the effect of Maillard reaction take place during baking (Caponio et al., 2015).
Hardness is associated with human perception of freshness and one of the important textural properties which is used to evaluate baked products (Karaoğlu and Kotancilar, 2009). Table 4 exhibits the hardness values (the peak force applied to break the biscuits on the test rig) obtained from force-time curves. The values of hardness showed that sample B2 was the softest (1320 $719 \mathrm{~N})$ and CS was the hardest $(1577 \pm 177 \mathrm{~N})$. It can be stated that adding ESP and OSP to biscuit formulations resulted in softer texture. This could be explained by looser matrix formation in the formulations which ESP and OSP added. Oksuz and Karakas (2016) studied the texture of gluten-free biscuits and they indicated that there was a positive correlation between the hardness values and the moisture content of the biscuits. Their finding is in agreement with the data obtained in this study which depicts that the force needed to crack the biscuits get greater as the moisture increases (Table 2 and Table 4). 


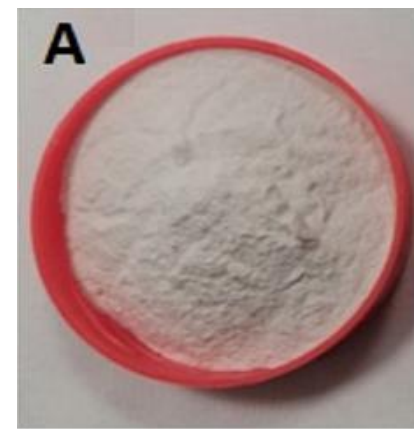

C

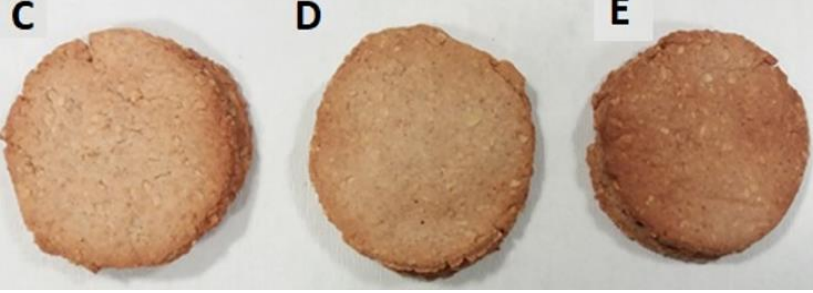

Figure. 1. Images of powder samples used and biscuit samples produced (A-egg shell powder, B-olive seed powder, Ccontrol sample, D-biscuit sample B1, E-biscuit sample B2)

The moisture is not an only factor affecting hardness, but also fat content that increases brittleness and other factors such as a more open and irregular structure of the sample, protein denaturation, loss of water-holding capacity, solubility of proteins and coagulation need to be taken into account (Pereira et al., 2013)

\section{Sensory Evaluation}

Sensory analysis is an important tool to be considered in new product development and evaluation. In order to investigate consumer preferences and the level of acceptance, consumer acceptability tests were conducted based on the determination of the magnitude of responses (likes and dislikes). In this work, 12 trained panellists were recruited and corresponding sensory scores for each of the attributes are presented in Table 5. All three biscuit formulations were assigned overall acceptability scores above 3.50 points on a scale of $1-5$ points by the panellists. Panellists agreed that sample B1 had better overall acceptability attribute than B2. Judging for individual properties, panellists had a greater preference for B2 samples in terms of hardness and distribution in mouth. B1 was given the greatest scores for general appearance, colour and overall acceptability. Even though CS was assigned higher points for taste and chewability attributes, it can be depicted from Table 5 that the differences in scores assigned to three biscuit formulations were not statistically significant. Therefore, adding OSP and ESP to biscuit formulation did not seem to adversely affect sensory properties of the biscuits.

\section{Conclusions}

The data obtained in this study revealed that incorporation of ESP and OSP in biscuit recipes yielded final products with different nutritional and textural properties. Fortification with food processing by-products, which are a good source of minerals and bioactive substances, has been identified as a process to improve biscuit nutrients and composition. In this piece of work, adding ESP and OSP was found to increase the mineral composition, TPC and AA of biscuit samples. Additionally, it increased darkness and decreased hardness. Results derived from sensory analysis demonstrated no significant differences $(\mathrm{P}<0.05)$ between the fortified and control samples. The results obtained in this study would be useful in improving biscuit quality and designing future studies as well as being a good example to utilization of food processing by-products to add value to products from the view of fulfilling consumers expectation for healthier products.

\section{Acknowledgements}

This work was financially supported by TUBITAK (The Scientific and Technological Research Council of Turkey) (Project No: 1139B411702502, Project Title: Biscuit with Egg Shell Powder, Olive Seed Powder and Oatmeal).

\section{References}

AACC, 2009. AACC International Approved Methods. AACC International Approved Methods. doi:10.1094/aaccint methods

Adebiyi JA, Obadina AO, Adebo OA, Kayitesi E. 2017. Comparison of nutritional quality and sensory acceptability of biscuits obtained from native, fermented, and malted pearl millet (Pennisetum glaucum) flour. Food Chemistry 232: 210-217. doi:10.1016/j.foodchem.2017.04.020

Afzal F, Mueen-ud-Din G, Nadeem M, Murtaza MA, Mahmood S. 2020. Effect of eggshell powder fortification on the physicochemical and organoleptic characteristics of muffins. Pure and Applied Biology 9: 1488-1496. https://doi.org/10. 19045/bspab.2020.90154

Apak R, Güçlü K, Özyürek M, Esin Karademir S, Erçağ E. 2006. The cupric ion reducing antioxidant capacity and polyphenolic content of some herbal teas. International Journal of Food Sciences and Nutrition. 57: 292-304. doi:10.1080/09637480600798132

Aslam HKW, Ur Raheem MI, Ramzan R, Shakeel A, Shoaib M, Sakandar HA. 2015. Utilization of Mango Waste Material (Peel, Kernel) To Enhance Dietary Fiber Content and Antioxidant Properties of Biscuit. Journal of Global Innovations in Agricultural and Social Sciences 2: 76-81. doi:10.17957/jgiass/2.2.533

Bajaj S, Urooj A, Prabhasankar P. 2006. Effect of incorporation of mint on texture, colour and sensory parameters of biscuits. International Journal of Food Properties 9: 691-700. doi:10.1080/10942910600547632

Brun LR, Lupo M, Delorenzi DA, Di Loreto VE, Rigalli A. 2013. Chicken eggshell as suitable calcium source at home. International Journal of Food Sciences and Nutrition 64: 740 743.

Caponio F, Gambacorta G, Summo C, Paradiso VM, Blanco A, Pasqualone A, Bianco AM. 2015. Production and characterization of functional biscuits obtained from purple wheat. Food Chemistry 180: 64-70. doi:10.1016/j. foodchem.2015.02.025

Choudhury M, Badwaik LS, Borah PK, Sit N, Deka SC. 2015. Influence of bamboo shoot powder fortification on physicochemical, textural and organoleptic characteristics of biscuits. Journal of Food Science and Technology 52: 6742-6748. doi:10.1007/s13197-015-1709-3

Chudzinska M, Baralkiewicz D. 2010. Estimation of honey authenticity by multielement characteristics using inductively coupled plasma-mass spectrometry (ICP-MS) combined with chemometrics. Food and Chemical Toxicology 48: 284-290. doi:10.1016/j.fct.2009.10.011 
Čukelj N, Novotni D, Sarajlija H, Drakula S, Voučko B, Curić D. 2017. Flaxseed and multigrain mixtures in the development of functional biscuits. LWT - Food Science and Technology 86: 85-92. doi:10.1016/j.lwt.2017.07.048

Cukelj N, Putnik P, Novotni D, Ajredini S, Voucko B, Curic D. 2016. Market potential of lignans and omega-3 functional cookies. British Food Journal doi:10.1108/BFJ-03-20160117

Dauda AO, Abiodun OA, Arise AK, Oyeyinka SA. 2018. Nutritional and consumers acceptance of biscuit made from wheat flour fortified with partially defatted groundnut paste. LWT - Food Science and Technology 90: 265-269. doi:10.1016/j.lwt.2017.12.039

Elbir M, Es-Safi NE, Amhoud A, Mbarki M. 2015. Characterization of phenolic compounds in olive stones of three moroccan varieties. MADERAS: Ciencia y tecnología 0-0. doi:10.4067/s0718-221x2015005000043

Fina BL, Brun LR, Rigalli A. 2016. Increase of calcium and reduction of lactose concentration in milk by treatment with kefir grains and eggshell. International Journal of Food Sciences and Nutrition 67: 133-140. https://doi.org/10.3109/09637486.2015.1137888

Grasso S, Omoarukhe E, Wen X, Papoutsis K, Methven L. 2019. The use of upcycled defatted sunflower seed flour as a functional ingredient in biscuits. Foods 8. https://doi.org/ $10.3390 /$ foods 8080305

Karaoğlu MM, Kotancilar HG. 2009. Quality and textural behaviour of par-baked and rebaked cake during prolonged storage. International Journal of Food Science \& Technology 44: 93-99. doi:10.1111/j.1365-2621.2007.01650.x

Krystyjan M, Gumul D, Ziobro R, Korus A. 2015. The fortification of biscuits with bee pollen and its effect on physicochemical and antioxidant properties in biscuits. LWT Food Science and Technology 63: 640-646. doi:10.1016/ j.lwt.2015.03.075

Mildner-Szkudlarz S, Bajerska J, Zawirska-Wojtasiak R, Górecka D. 2013. White grape pomace as a source of dietary fibre and polyphenols and its effect on physical and nutraceutical characteristics of wheat biscuits. Journal of the Science of Food and Agriculture 93: 389-395. doi:10.1002/jsfa.5774

Mittal A, Teotia M, Soni RK, Mittal J. 2016. Applications of egg shell and egg shell membrane as adsorbents: A review. Journal of Molecular Liquids doi:10.1016/j.molliq.2016. 08.065

Naves MMV, Fernandes DC, Prado CMM, Teixeira LSM. 2007. Food fortification with egg shell powder as a calcium source. Ciência e Tecnologia de Alimentos 27: 99-103. https://doi.org/10.1590/s0101-20612007000100017
Niju S, Begum MMMS, Anantharaman N. 2014. Modification of egg shell and its application in biodiesel production. Journal of Saudi Chemical Society 18: 702-706. doi:10.1016/j.jscs. 2014.02.010

Nunes MA, Pimentel FB, Costa ASG, Alves RC, Oliveira MBPP. 2016. Olive by-products for functional and food applications: Challenging opportunities to face environmental constraints. Innovative Food Science and Emerging Technologies doi:10.1016/j.ifset.2016.04.016

Oksuz T, Karakas B. 2016. Sensory and textural evaluation of gluten-free biscuits containing buckwheat flour. Cogent Food, Agriculture 2. doi:10.1080/23311932.2016.1178693

Pasqualone A, Bianco AM, Paradiso VM, Summo C, Gambacorta G, Caponio F. 2014. Physico-chemical, sensory and volatile profiles of biscuits enriched with grape marc extract. Food Research International 65: 385-393. doi:10.1016/j.foodres. 2014.07.014

Pereira D, Correia PMR, Guiné RPF. 2013. Analysis of the physical-chemical and sensorial properties of Maria type cookies. Acta Chimica Slovaca 6: 269-280. doi:10.2478/acs2013-0040

Rababah TM, Al-Mahasneh MA, Ereifej KI. 2006. Effect of chickpea, broad bean, or isolated soy protein additions on the physicochemical and sensory properties of biscuits. Journal of Food Science 71. doi:10.1111/j.1750-3841.2006.00077.x

Rodríguez G, Lama A, Rodríguez R, Jiménez A, Guillén R, Fernández-Bolaños J. 2008. Olive stone an attractive source of bioactive and valuable compounds. Bioresource Technology 99(13): 5261-9. doi:10.1016/j.biortech.2007.11. 027

Rupasinghe HPV, Wang L, Huber GM, Pitts NL. 2008. Effect of baking on dietary fibre and phenolics of muffins incorporated with apple skin powder. Food Chemistry 107: 1217-1224. doi:10.1016/j.foodchem.2007.09.057

Salem I, Ammar A, Habiba R. 2012. Effect of Eggshell Powder Addition as a Source of Calcium Fortification on Butter Cake Quality. Journal of Agriculture and Veterinary Science 5: 109-118.

Sarkis JR, Côrrea APF, Michel I, Brandeli A, Tessaro IC, Marczak LDF. 2014. Evaluation of the phenolic content and antioxidant activity of different seed and nut cakes from the edible oil industry. JAOCS, Journal of the American Oil Chemists' Society 91: 1773-1782. doi:10.1007/s11746-0142514-2

Silva F de O, Miranda TG, Justo T, Frasão B da S, Conte-Junior CA, Monteiro M, Perrone D. 2018. Soybean meal and fermented soybean meal as functional ingredients for the production of low-carb, high-protein, high-fiber and high isoflavones biscuits. LWT - Food Science and Technology 90: 224-231. doi:10.1016/j.lwt.2017.12.035 